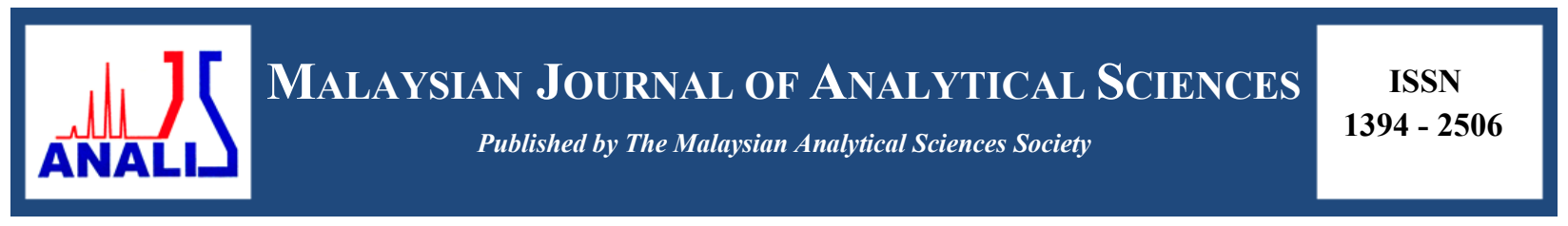

\title{
SENSORY EVALUATION AND QUANTITATIVE ANALYSIS OF MINERAL AND HEAVY METAL CONTENT OF PROTEIN SUPPLEMENT INCORPORATED WITH HERBAL EXTRACT
}

\author{
(Penilaian Rasa dan Analisa Kuantitatif Kandungan Mineral dan Logam Berat bagi \\ Makanan Tambahan Protin Digabungkan dengan Ekstrak Herba) \\ Noor Azwani Zainol ${ }^{1 *}$, Nor Farahiyah Aman Nor $^{1}$, HarisunYa'akob ${ }^{1,2}$, Siti Nor Azlina Abd Rashid ${ }^{1}$, \\ Siti Hajar Mat Sarip ${ }^{1}$, Ramlan Aziz ${ }^{1,2}$ \\ ${ }^{1}$ Institute of Bioproduct Development \\ ${ }^{2}$ Faculty of Chemical Engineering \\ Universiti Teknologi Malaysia 81310 UTM Johor Bahru, Johor, Malaysia \\ *Corresponding author: azwani@ibd.utm.my
}

Received: 7 November 2016; Accepted: 18 September 2017

\begin{abstract}
Calories-dense products promote weight gain through its healthy ingredients. The incorporation of herbs increased the product's benefit with antioxidant, anti-cancer and anti-aging properties. In this study, the comparison between herbal and non-herbal (commercial products) protein supplements were determined. The sensory evaluation of the protein supplements were done via 9-point hedonic scale. The mineral contents and undesirable toxic metals in the the product were also analysed using Inductively Coupled Plasma-Mass Spectrometry (ICP-MS). The score of hedonic scale indicated that the sweetness and bitterness of the herbal protein supplement were significantly different compared to the commercial products. All samples showed differences in the mineral contents where the herbal protein supplement contributed the highest content of magnesium $(\mathrm{Mg}) 3643.7 \mu \mathrm{g} / \mathrm{kg}$, sodium $(\mathrm{Na}) 8192.3 \mu \mathrm{g} / \mathrm{kg}$ and ferum $(\mathrm{Fe}) 180.7 \mu \mathrm{g} / \mathrm{kg}$. The ICP-MS analysis result showed traces of heavy metals (cadmium, arsenic, plumbum, mercury) were $1.10 \mu \mathrm{g} / \mathrm{kg}, 0.03 \mu \mathrm{g} / \mathrm{kg}, 3.00 \mu \mathrm{g} / \mathrm{kg}$ and $5.07 \mu \mathrm{g} / \mathrm{kg}$, respectively. These results confirmed that the concentrations of heavy metals in the product has not exceeded the maximum standard limit of regulation in Malaysia for Cd $(0.3 \mathrm{mg} / \mathrm{kg})$, As $(5 \mathrm{mg} / \mathrm{kg}), \mathrm{Pb}(10 \mathrm{mg} / \mathrm{kg})$, and $\mathrm{Hg}(0.5 \mathrm{mg} / \mathrm{kg})$. Hence, the results might be useful to define the new formulations of these highly consumed protein supplement with health benefits for atheletes.
\end{abstract}

Keywords: protein supplement, mineral content, heavy metal content, hedonic scale

\begin{abstract}
Abstrak
Produk-produk padat kalori menggalakkan penambahan berat melalui ramuan-ramuan sihatnya. Penambahan herba meningkatkan kebaikan produk seperti ciri-ciri antioksida, anti-kanser dan anti-penuaan. Di dalam kajian ini, perbandingan di antara makanan tambahan protein berherba dan tidak berherba (produk komersil) telah diperolehi. Ujian rasa terhadap makan tambahan protin ini telah dilakukan melalui 9-titik skala hedonik. Kandungan mineral dan logam toksik yang tidak dikehendaki di dalam produk turut dianalisa menggunakan Spektrometri Jisim-Plasma Ganding Secara Aruhan (ICP-MS). Skor skala hedonik menujukkan kemanisan dan kepahitan makanan tambahan berprotin berbeza secara ketara berbanding produk-produk komersil. Semua sampel menunjukkan perbezaan di dalam kandungan mineral, di mana makanan tambahan protin berherba menyumbang kandungan tertinggi untuk magnesium $(\mathrm{Mg}) 3643.7 \mu \mathrm{g} / \mathrm{kg}$, sodium $(\mathrm{Na}) 8192.3 \mu \mathrm{g} / \mathrm{kg}$ dan ferum $(\mathrm{Fe}) 180.7 \mu \mathrm{g} / \mathrm{kg}$. Analisa keputusan ICP-MS menunjukkan kandungan logam berat (kadmium, arsenik, plumbum, merkuri) adalah $1.10 \mu \mathrm{g} / \mathrm{kg}, 0.03$ $\mu \mathrm{g} / \mathrm{kg}, 3.00 \mu \mathrm{g} / \mathrm{kg}$ dan $5.07 \mu \mathrm{g} / \mathrm{kg}$ setiap satunya. Hasil ini mengesahkan kepekatan logam berat tidak melebihi piawaian kadar maksimum peraturan Malaysia untuk Cd(0.3 mg/kg), As (5 mg/kg), Pb(10 mg/kg), and $\mathrm{Hg}(0.5 \mathrm{mg} / \mathrm{kg})$. Oleh itu, keputusan yang
\end{abstract}




\section{Noor Azwani et al: SENSORY EVALUATION AND QUANTITATIVE ANALYSIS OF MINERAL AND HEAVY METAL CONTENT OF PROTEIN SUPPLEMENT INCORPORATED WITH HERBAL EXTRACT}

diperolehi mungkin berguna untuk menterjemah formulasi-formulasi baru yang banyak digunakan bagi makanan tambahan protin yang bermanfaat kepada kesihatan untuk atlet.

Kata kunci: makanan tambahan protin, kandungan mineral, kandungan logam berat, skala hedonik

\section{Introduction}

The Malaysian sports nutrition industry benefited a 2\% value of compound annual growth rate (CAGR) in 2014. Sports nutrition products in Malaysia will continue to have a strong sales demand specifically for men [1]. The increasing number of sports nutrition outlets in major shopping malls will also facilitate sales growth of wide ranges of sports nutritions. Protein supplement, specifically protein shakes is one of the examples of a sport nutrition drink. The protein supplement is added to the diet, mainly as is it contain vitamins, minerals, amino acids, herbs or botanicals, metabolites/constituents/extracts or a combination of any of these ingredients [2]. Sportperson prefers protein supplement as it easy to be prepared as a drink. The protein supplement is also able to speed up the recovery of strained muscles. These features are particularly important for athletes, bodybuilders, or people who need to gain muscle mass and strength while losing fat $[3,4]$.

The main ingredients used in protein supplement are whey protein, branch chain amino acid (BCAA), sweeteners, creatine, and glutamine. Consuming whey protein is a healthy way to add more protein in the daily diet. The whey protein is a quality protein source; that is absorbed and utilized efficiently by the human body [5]. The whey protein can be digested quickly and performs rapid delivery of amino acid to muscle cell which serves as a building block to increased muscle growth [6]. Meanwhile, the use of beta-alanine is to promote delay in muscle fatigue after workout with regard to the increasing levels of carnosine in intra-muscular. For synergistic effect, creatine is added in order to increase muscle volume and promoting lean body mass as well as increased in post-workout recovery [7]. Apart from that, glutamine promotes durability when connected to high muscle usage [8]. The intake of glutamine allows a person to be actively involved in exercises in longer period and with less fatigue [9].

Currently, there are a lot of protein supplements available in the market which can be used as directed. However, a lot of protein supplements which are commercially available may contain andro-steroids and most of the products are high level in sugar content. Andro-supplements acts like a steroid once it is metabolized by the body and therefore can pose similar kinds of health risks as steroids. The andro-supplements claim to be converted into testosterone in the body to help improve muscle mass. However, in 2004, the U.S. Food and Drug Administration (FDA) declared the andro- supplements are illegal, citing safety concerns [10].

The incorporation of herbs in the formulation of protein supplement is targeted to support a healthy lifestyle while contributing to the growth and maintenance of lean muscle mass. By adding the herbs in the ingredient such as Eurycoma longifolia (TA) may give a significant effect to sportperson for a long-lasting endurance during performing activities. The Tongkat Ali itself can act naturally as andro-supplement, which helps to boost the energy and increases stamina during the workout and/or activity. In parallel, it also promotes wellness with reference to its chemical components which are rich in phytonutrients [11]. Simultaneously, Tribulus terristeris has been used to enhance overall health, support healthy libido function and amplify muscle tone [12]. The Safed muesli (Chlorophytum borivilianum) is used as an energy booster and generally strengthens body immune system. The addition of herbal extract is also ideal for those who is lacking in consuming vegetables due to rich in vitamins and mineral [13].

Minerals plays an important role to support the metabolism of all living creatures [14]. Mineral contents such as selenium, zinc and copper are essential to maintain the metabolism of the human body; the optimal function for cell growth, healing and the activity of many metabolic processes [15]. Meanwhile, heavy metals such as cadmium, arsenic, lead and mercury can lead to adverse effects, although they are only present in small quantity [16]. Regular consumption of protein supplement may contribute to an increase intake of both mineral and heavy metal contents by the human body [17]. Therefore, it is necessary to give a guideline of the average amount to be consumed safely by the consumers. Contamination of heavy metals in the supplements during preparation and/or the use of heavy metal in the supplements itself is increasing especially when dealing with plants $[18,19]$. This contamination might 
result in serious health hazards such as dysfunction of kidney and symptoms of chronic toxicity [20, 21] when over consumed.

The innovation of products with healthy ingredients of Eurycoma longifolia, Tribulus terristris and Chlorophytum borivilianum with less sugar content is highly favourable to the sports industry. With balanced combination of fats, proteins, carbohydrates and minerals content, it will help sport persons such as athletes, body builders, and gymgoers to increase muscle size in a healthier way. Since the incorporation of the herbs are relatively new in the market, this study would provides information on the safety guideline of protein supplements with focus on essential mineral content and evaluate the level of heavy metal in the protein supplement. Commercial products of protein supplements were also analysed for its mineral and heavy metal content for comparison. The sensory attributes such as bitterness, sweetness, aftertaste, appearance and overall acceptability were also identified for use in future product formulation.

\section{Ingredients formulation}

\section{Materials and Methods}

The guidelines for the ingredients for the initial product formulation as well as the method of preparation were obtained from a commercial protein supplement. The ingredients chosen for this research were focused on developing the best formulation, with less sugar content and high in essential mineral including protein content. The ingredients of the formulations were obtained from health store at Taman Universiti, Skudai, Johor. Three commercial products categorized as food supplement were purchased for comparison purposes and labeled as sample CML 1, CML 2 and CML 3.

\section{Preparation of formulated protein supplement}

The main herbs used in this product were prepared as follows; Tongkat Ali powder were prepared from extracted root part using water with the ratio $(1: 8 \mathrm{w} / \mathrm{v})$ and then spray dried using spray dryer (Gea Niro, Italy). The spray dried parameter used were as follows : air inlet temperature at $160{ }^{\circ} \mathrm{C}$, feed temperature at $25^{\circ} \mathrm{C}$, air pressure at $17.91 \mathrm{psi}$ and feed flow rate at $4.86 \mathrm{~mL} / \mathrm{min}$. The parameter used was at the optimum condition. All other ingredients which formulated were then mixed together using fine grinder until homogenized. The prepared sample were sealed, packed and stored at room temperature for further required test.

\section{Mineral content and heavy metal analysis: Digestion procedures}

For the digestion of the samples, a representative of $0.5-1$ gram of dry weight sample is digested with $1 \mathrm{~mL}$ of $60 \%$ analytical grade Nitric acid (Sigma Aldrich, Germany) and ultrapure water (Hitachi, Japan). The digestate was heated using a hot plate under boiling temperature until white vapour appeared. The sample was then diluted with ultrapure water until it reaches a $100-\mathrm{mL}$ final volume. The sample is filtered using 0.25 nylon syringe filter and ready for Inductively Coupled Plasma-Mass Spectrometry (ICP-MS) injection.

For the precise quantification of heavy metal and mineral contents, calibration against synthetic standards was used before running the sample. $1000 \mu \mathrm{g} / \mathrm{kg}$ multi-element standard was used from Perkin Elmer standard solution and diluted to $10,20,30,50 \mu \mathrm{g} / \mathrm{kg}$ and $25 \mu \mathrm{g} / \mathrm{kg}$ as Quality Control (dissolved with $1 \%$ nitric acid (Sigma Aldrich, Germany)) for mercury determination Gold ( $\mathrm{Au})$ standard solution was used with same concentrations. The data acquisition was done by ICP-MS Software (ELAN 6100, Perkin Elmer).

\section{ICP-MS instrumentation}

The ICP-MS (ELAN 6100, Perkin Elmer) was used for heavy metal and mineral content analysis in the samples. The instrument was setup via an integrated all lines system including; 1000 Watts Inductively Couple plasma radiofrequency (ICP RF) Power. Other conditions were set as follows; plasma flow, auxiliary flow and nebulizer flow, at $15 \mathrm{~L} \mathrm{~min}^{-1}, 1.5 \mathrm{~L} \mathrm{~min}{ }^{-1}$ and $0.47 \mathrm{~L} \mathrm{~min}^{-1}$, respectively. The samples were introduced after an initial delay of 25 seconds. Afterward, the samples were pumped at the rate of $10 \mathrm{rpm}$ and 25 seconds rinse time. The concentrations were read within 5 seconds for each replicates and an instrument stabilization time of 15 seconds was allowed between the samples. 


\section{Noor Azwani et al: SENSORY EVALUATION AND QUANTITATIVE ANALYSIS OF MINERAL AND \\ HEAVY METAL CONTENT OF PROTEIN SUPPLEMENT INCORPORATED WITH \\ HERBAL EXTRACT}

\section{Sensory analysis: Subjects}

Fifty subjects consisting of volunteers (comprising of 26 men and 24 women) from University Teknologi Malaysia (UTM) have taken part in the sensory evaluation session. They were led by an experienced facilitator and lasted for 10 minutes. They were given instructions and the objective of the sensory evaluation. The explanation included descriptions of the attributes and their implied acceptability in the two samples; commercial product (CML 1) and formulated protein supplement product (FMD 1). These protein supplements were purposely developed as to compare with the commercial samples.

The attributes generated from the participants included sweetness, bitterness, aftertaste, appearance and overall preference. All five sensory attributes were measured using the 9-point hedonic scale. The scale values ranged from 'Like extremely' to 'dislike extremely', corresponding to the highest and lowest scores of ' 9 ' to ' 1 ', respectively.

\section{Sample preparation for sensory evaluation}

Only one of the commercial products was chosen as a comparison with the formulated protein supplement product. The samples were labeled with 3-digit random number and samples were presented simultaneously. Purified water was used to clean the palate. The order of the presentation was balanced and randomised to eliminate contrasting effect and positional bias.

\section{Statistical analysis}

The sensory scores for the protein supplement were subjected to the analysis of variance (ANOVA) to determine if there were statistically significant $(\mathrm{P} \leq 0.05)$ preferences in sensory attributes [22]. Tukey's test was used to determine which of the formulation was higly preferred [23, 24].

\section{Mineral and heavy metal content}

\section{Results and Discussion}

The results of mineral content and heavy metal analysis are presented in Table 1 and Table 2, respectively. Table 1 shows the mineral analysis of CML 1, CML 2, CML 3 and FMD 1. In general (Table 1) sodium and magnesium were the two major components presenet in all of the samples, and followed by ferum. The results obtained for sodium $(8192.3 \mu \mathrm{g} / \mathrm{kg})$, magnesium $(3643.7 \mu \mathrm{g} / \mathrm{kg})$ and ferum $(180.7 \mu \mathrm{g} / \mathrm{kg})$ for formulated protein supplement (FMD 1) were higher compared to the commercial products. Magnesium significantly contributed to the digestive and kidney health level while sodium is important as it isrelated to cardio activities [25]. Ferum is important for its protein transport activities specifically related to the circulatory of blood to the cells [26]. The results obtained from the formulated protein supplement showed a presence of $42.6 \mu \mathrm{g} / \mathrm{kg}$ of zinc, $23.6 \mu \mathrm{g} / \mathrm{kg}$ of manganese, $18.3 \mu \mathrm{g} / \mathrm{kg}$ of chromium, $16.9 \mu \mathrm{g} / \mathrm{kg}$ of copper and $2 \mu \mathrm{g} / \mathrm{kg}$ of selenium. These result was also comparable to the commercial products. Based on the ASEAN Guideline for herbal supplement, the daily dietary intake for adults are as follow; $350 \mathrm{mg}$ of magnesium, $20 \mathrm{mg}$ of ferum, $15 \mathrm{mg}$ of zinc, $3.5 \mathrm{mg}$ of manganese and selenium at $0.2 \mathrm{mg}$. All of these minerals play an important role in our body as it is related to bioavailability and physiological action where they act as a co-factor in metabolic processes [27].

Table 1. Mineral components of commercial and formulated protein supplement in $\mu \mathrm{g} / \mathrm{kg}$

\begin{tabular}{lcccc}
\hline \multirow{2}{*}{ Minerals Contents } & \multicolumn{4}{c}{ Protein Supplements } \\
\cline { 2 - 5 } & CML 1 & CML 2 & CML 3 & FMD 1 \\
\hline Sodium & 953.3 & 1116.7 & 2645.9 & 8192.3 \\
Ferum & 74.4 & 134.6 & 106.7 & 180.7 \\
Magnesium & 1342.6 & 1378.2 & 2309.8 & 3643.7 \\
Selenium & 0.4 & 0.3 & 0.6 & 2.0 \\
Zinc & 52.6 & 36.0 & 63.8 & 42.6 \\
Manganese & 13.3 & 22.8 & 30.4 & 23.6 \\
\hline
\end{tabular}


Table 2. Heavy metals of commercial products and herbal protein supplements in $\mu \mathrm{g} / \mathrm{kg}$

\begin{tabular}{lcccc}
\hline \multirow{2}{*}{ Heavy Metal contents } & \multicolumn{4}{c}{ Protein Supplements } \\
\cline { 2 - 5 } & CML 1 & CML 2 & CML 3 & FMD 1 \\
\hline Plumbum & $2.42^{\mathrm{a}}$ & $1.49^{\mathrm{a}}$ & $5.87^{\mathrm{ab}}$ & $3.00^{\mathrm{a}}$ \\
Arsenic & $0.03^{\mathrm{a}}$ & $0.05^{\mathrm{a}}$ & $0.02^{\mathrm{a}}$ & $0.03^{\mathrm{a}}$ \\
Mercury & $5.12^{\mathrm{a}}$ & $4.80^{\mathrm{a}}$ & $5.01^{\mathrm{a}}$ & $5.07^{\mathrm{a}}$ \\
Cadmium & $0.56^{\mathrm{a}}$ & $1.00^{\mathrm{ab}}$ & $0.61^{\mathrm{a}}$ & $1.10^{\mathrm{ab}}$ \\
Chromium & $10.6^{\mathrm{a}}$ & $10.0^{\mathrm{a}}$ & $7.0^{\mathrm{a}}$ & $18.3^{\mathrm{ab}}$ \\
Cuprum & $11.2^{\mathrm{a}}$ & $15.2^{\mathrm{a}}$ & $20.4^{\mathrm{ab}}$ & $16.9^{\mathrm{a}}$ \\
\hline *Means in rows and columns with different superscripts differ $(\mathrm{p} \leq 0.05)$.
\end{tabular}

The results obtained in Table 2 refer to the presence of heavy metal content of all protein supplements. In general, mercury, plumbum, cadmium, and arsenic were detected in all samples; however, at a lower detection limit. Based on the National Pharmaceutical Control Bureau (Ministry of Health, Malaysia), the guideline for maximum level permitted for metal contaminant in food product, are as follow; mercury $(\leq 0.5 \mathrm{ppm})$, cadmium $(\leq 0.3 \mathrm{ppm})$, plumbum $(\leq 10 \mathrm{ppm})$, arsenic $(\leq 5.0 \mathrm{ppm})$, chromium $(0.5 \mathrm{mg})$ and copper $(2 \mathrm{mg})$. Plumbum $(\mathrm{Pb})$, cadmium $(\mathrm{Cd})$, arsenic (As) and mercury (Hg) are considered as toxic to human body, therefore, their daily intake via supplements has been restricted. Limitation of intakes of $\mathrm{As}, \mathrm{Cd}, \mathrm{Hg}$, and $\mathrm{Pb}$ were assessed with respect to the safety levels described by various national and public health organizations [28].

\section{Acceptance of the formulation}

A sensory analysis was carried out at a lab-scale test to verify whether the addition of Tongkat Ali herbs would affect the acceptance of the product. In general protein supplement added with herbs was accepted as there is no significant difference compared to the commercial protein supplement where the score were 3.43 and 3.46, respectively as in Table 3. The sensory scores of sweetness, bitterness, aftertaste, appearance and overall acceptability assigned by the panellists were presented in Figure 1. It was observed that the sweetness, bitterness and appearance score were significantly different at $(p \leq 0.05)$ as in Table 3 . Meanwhile, it was observed that the aftertaste score was not significantly different at $(\mathrm{p} \leq 0.05)$. The sweetness of the protein supplement needs to be addressed since consumers tend to reduce food intake when they consumed high glucose products. Glucose in solution would be expected to pass rapidly to the small intestine and stimulate the satiety hormones including CCK [29] and polypeptide YY [30]. As a result, this may increase the possibilities of lacking other important nutrients which in turn might increase the risk to health problem. The aftertaste attributes is one of the important attributes as this will affect consumers to like or dislike the products. The component which could also contribute to bitter aftertaste are low-calorie products such as saccharin and acesulfame-K [31]. The low sensory score for the bitterness of the formulated protein supplement was probably because of Tongkat Ali powder extract added in the formulation. This bitter tastes in the protein supplement is probably mainly due to the eurycomanone compound in Tongkat Ali. Eurycomanone is one of the phytochemical compounds which can be found in Tongkat Ali extract and was identified as one type of quassiniods which responsible for the bitter taste [32]. 


\section{Noor Azwani et al: SENSORY EVALUATION AND QUANTITATIVE ANALYSIS OF MINERAL AND HEAVY METAL CONTENT OF PROTEIN SUPPLEMENT INCORPORATED WITH HERBAL EXTRACT}

Table 3. Mean sensory scores for protein supplements

\begin{tabular}{lcc}
\hline \multirow{2}{*}{ Sensory Attributes } & \multicolumn{2}{c}{ Formulation } \\
\cline { 2 - 3 } & Commercial (CML 1) & Formulated (FMD 1) \\
\hline Sweetness & $3.62^{\mathrm{a}}$ & $3.07^{\mathrm{ab}}$ \\
Bitterness & $3.00^{\mathrm{a}}$ & $3.43^{\mathrm{ab}}$ \\
Aftertaste & $3.87^{\mathrm{a}}$ & $3.67^{\mathrm{a}}$ \\
Appearance & $3.83^{\mathrm{ab}}$ & $4.03^{\mathrm{ab}}$ \\
Overall & $3.43^{\mathrm{a}}$ & $3.46^{\mathrm{a}}$ \\
\hline
\end{tabular}

ab There are statistically significant preferences $(\mathrm{P} \leq 0.05)$ of one sample over the other(s) with respect to the particular sensory attributes if values in the same row carry different superscripts; that is if calculated t-value $>$ tabulated t-value.

CML 1

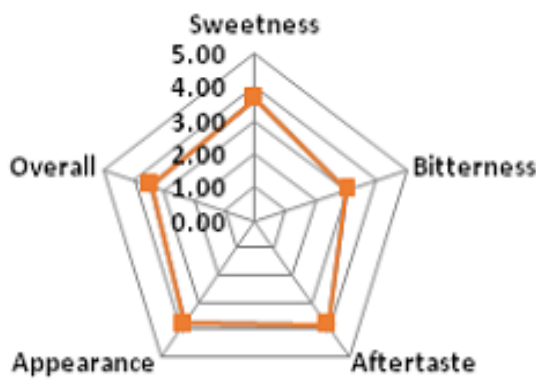

FMD 1

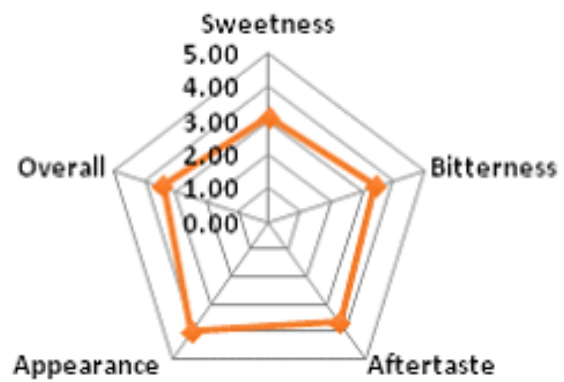

Figure 1. Comparison of sensory attributes for commercial (CML 1) and formulated (FMD 1) product of protein supplements

\section{Conclusion}

Based on the overall results, incorporation of herbal powder significantly affected the bitterness and sweetness of protein supplement products. The addition of herbs in the protein supplement is also important as it increased the mineral intake which is good to promote a healthy diet. Based on the result obtained, protein supplement added with Tongkat Ali satisfactorily contribute to nutritional values if compared to other products available in the market. Since there is no significant difference between commercial and formulated product in overall acceptability of the products, it may be concluded that this formulated product may have the potential to be commercial.

\section{Acknowledgement}

The authors sincerely acknowledge the support provided by Platinum Company Sdn. Bhd. and Institute Bioproduct Development, (IBD), UTM, Malaysia for the technical assistance.

\section{References}

1. Euromonitor. (2006). Sports nutrition in Malaysia. Retrieved from www.utm.my/psz on 14 January 2017.

2. Barnes, J. (2003). Efficacy and safety of complementary medicines: Fashions, facts and the future. Part 1. Regulation and quality, British Journal of Clinical Pharmacology, 55: 226 - 233.

3. Ohtani, M., Sugita, M. and Maruyama, K. (2006). Amino acid mixture improves training efficiency in athletes. Journal of Nutrition, 136: $538-543 \mathrm{~S}$. 
4. Sugita, M., Ohtani, M., Ishii, N., Maruyama, K. and Kobayashi K. (2003). Effect of a selected amino acid mixture on the recovery from muscle fatigue during and after eccentric contraction exercise training. Bioscience, Biotechnology and Biochemistry, 67: 372 - 375

5. World Health Organization (2004). WHO traditional medicine strategy 2002-2005; WHO: Geneva, Switzerland.

6. Carol B. (2010). Whey protein: A functional food. The Nutrition Practitioner, 1-8.

7. Haussinger, D., Lang, F. and Gerok, W. (1994). Regulation of cell function by the cellular hydration state. American Journal of Physiology, 267: 343 - 355.

8. Newsholme, E. A. (2001). Why is L-glutamine metabolism important to cells of the immune 55 system in health, post-injury, surgery, or infection. Journal of Nutrition, 131: $2515-2522$.

9. Antonio, J. and Street, C. (1999). Glutamine: A potentially useful supplement for athletes. Canadian Journal of Applied Physiology, 24(1): 1 - 14.

10. Food and Drug Administration (2009). Public health advisory: the FDA recommends that consumers should not use body building products marketed as containing steroids or steroid-like substances. Retrieved from http://www.fda.gov/Drugs/DrugSafety on 17 January 2017.

11. Marshall, K. (2004). Therapeutic applications of whey protein. Alternative Medicine Review, 9(2): 136 - 156.

12. Islam, M. S., Ali, S., Rahman, M., Islam, R., Ali, A., Azad, A. K. and Islam, M. R. (2011). Antidiabetic, cytotoxic activities and phytochemical screening of Peltophorum pterocarpum (DC) K. Heyne root. Journal of Medicinal Plants Research, 5(16): $3745-3750$.

13. Pokrywka, A., Obminski, Z., Fijalek, Z., Turek-Lepa, E., Grucza, R. and Malczewska L. (2014). Insights into supplements with Tribulus terrestris used by Athletes.

14. Vibhute, B. P., Bhide, D. R., Karadbhajne, V. Y., Kulkarni, A. S. and Khotpal, R. R. (2013). Fatty acid profile of pumpkin and bael seed lipids of Central India Region. Research and Reviews Journal of Botanical Sciences, 2(2): $1-3$.

15. Stitch, S. R. (1957). Trace elements in human tissue. 1. A semi-quantitative spectrographic survey. Biochemical Journal, 67: 97 - 103.

16. Ajasa, M. A., Bello, O. M., Ibrahim, O. M., Ogunwande, A. I. and Olawore, O. N. (2004). Heavy metals and macronutrients status in herbal plants of Nigeria. Food Chemistry., 85: 67 - 71.

17. Gosslim, R. E., Smith, R. P., Hodge, H. C. and Braddock, J. E. (1984). Clinical Toxicology of Commercial Products, $5^{\text {th }}$ edition; Willians \& Wilkins: Baltimore, MD, USA, pp. 437.

18. Schilcher, H. (1987). Possibilities and limitations of phytotherapy. Pharmaceutish Weekblad - Scientific Edition, 9(4): 215.

19. Andrew, A. S., Warren, A. J., Barchowsky, A., Temple, K. A., Klei, L., Soucy, N. V., O’Hara, K. A. and Hamilton, J. W. (2003). Genomic and proteomic profiling of responses to toxic metals in human lung cells. Environmental Health Perspective, 111: 825 - 835.

20. Shaw, D. Leon, C. Kolev, S. and Murray, V. (1997). Traditional remedies and food supplements. A 5-year toxicological study (1991-1995). Drug Safety, 17: 342 - 356.

21. Kreider R. (1999). Dietary supplements and the promotion of muscle growth with resistance exercise. Sports Medicine, 27: 97 - 110.

22. Macfie, H. J., Bratchell, N., Grenhoff, K. and Valis, L.V. (1989). Designs to balance the effect of order of presentation and first-order carry-over in hall tests. Journal of Sensory Studies, 4: $129-132$.

23. Kramer, A. and Twigg, B. A. (1970). Quality control for the food industry (3 ${ }^{\text {rd }}$ Edition). Westport: AVI Publishing Company Incorporation.

24. Larmond, E. (1977). Laboratory methods for sensory evaluation of food. Canadian Government Publishing Centre.

25. Soetan, O. K, Olaiya, C. O and Oyewole O. E. (2010). The importance of mineral elements for humans, domestic animals and plant: A review. African Journal of Food Science, 4(5): 200 - 222.

26. National Academy Press. (2001). Institute of Medicine. iron. In: dietary reference intakes for vitamin a, vitamin $\mathrm{k}$, arsenic, boron, chromium, copper, iodine, iron, manganese, molybdenum, nickel, silicon, vanadium, and zinc; pp. $290-393$.

27. Hathcock, J. N. (2004). Vitamin and mineral safety, $2^{\text {nd }}$ (Edition). Council for responsible nutrition. Washington. pp 169. 
28. Bharathi, A., Yan-Hong, W., Duzgoren-Aydin, N. S. and Khan, I. A. (2011). Inorganic elemental compositions of commercial multivitamin/mineral dietary supplements: Application of collision/reaction cell inductively coupled-mass spectroscopy. Food Chemistry, 127: $54-62$.

29. Hall, W. L., Millward, D. J., Long, S. J. and Morgan, L. M. (2003). Casein and whey exert different effects on plasma amino acid profiles, gastrointestinal hormone secretion and appetite. British Journal of Nutrition, 89: $239-248$.

30. Batterham, R. L., Heffron, H., Kapoor, S., Chivers J. E., Chandarana, K. and Herzog, H. (2006). Critical role for peptide YY in protein-mediated satiation and body-weight regulation. Cell Metabolism, 4: $223-233$

31. Kuhn, C., Bufe, B., Winnig, M., Hofmann, T., Frank, O., Behrens, M., Lewtschenko, T., Slack, J. P., Ward, C. D. and Meyerhof, W. (2004). Bitter taste receptors for saccharin and acesulfame-K. Journal of Neuroscience, 24(45): $10260-10265$.

32. Low, B. S., Choi, S. B., Abdul Wahab, H., Das, P. K. and Chan, K. L (2013). Eurycomanone, the major quassinoid in Eurycoma longifolia root extract increases spermatogenesis by inhibiting the activity of phosphodiesterase and aromatase in steroidogenesis. Journal of Ethnopharmacology, 149(1): 201 - 207. 